\title{
Solitary pulmonary nodule caused by Schistosoma mansoni in a patient with medullary thyroid carcinoma
}

\author{
Nódulo pulmonar solitário causado pelo Schistosoma mansoni \\ em paciente com carcinoma medular da tireóide
}

José Roberto Lambertucci ${ }^{1}$, Ricardo Fontes Moreira ${ }^{1}$ and Alfredo José Afonso Barbosa ${ }^{2}$

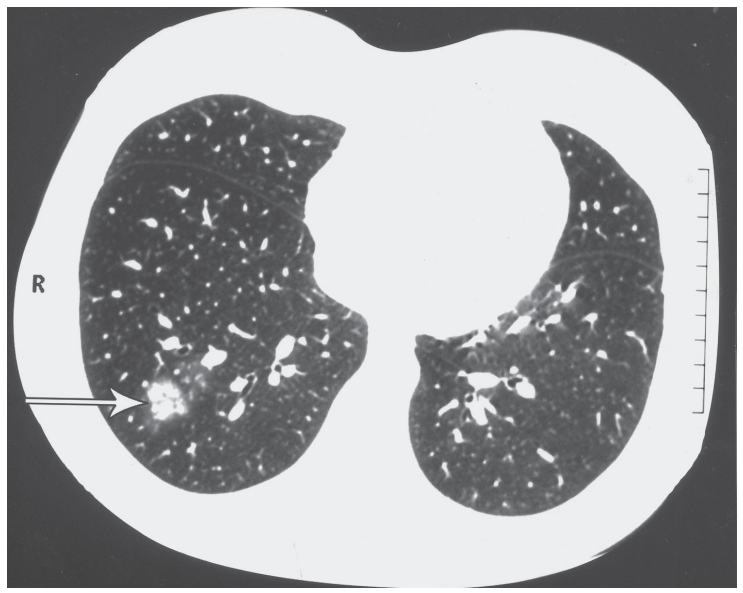

A

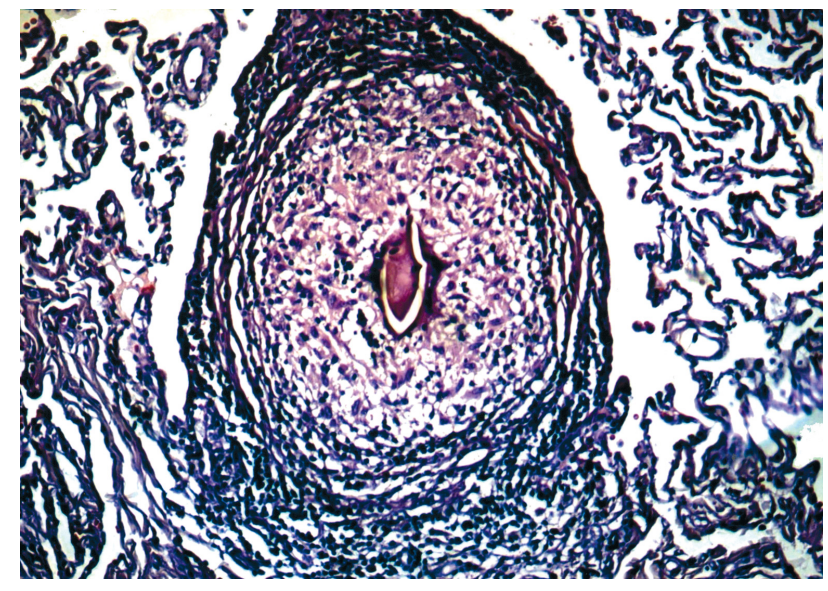

B



C

1. Serviço de Doenças Infecciosas e Parasitárias da Faculdade de Medicina da Universidade Federal de Minas Gerais, Belo Horizonte, MG, Brasil. 2. Departamento de Anatomia Patológica da Faculdade Medicina da Universidade Federal de Minas Gerais, Belo Horizonte, MG, Brasil.

Address to: Prof. José Roberto Lambertucci. Deptº de Clínica Médica/FM/UFMG. Avenida Alfredo Balena 190, 30130-100 Belo Horizonte, MG, Brasil.

e-mail: lamber@uai.com.br

Recebido para publicação em 5/7/2005

Aceito em 20/8/2005 
A 33-year-old woman was submitted to total thyroidectomy for treatment of a medullary thyroid carcinoma seven years before the present admission to hospital. Since then, she has been periodically submitted to clinical and laboratory examinations to detect recurrence of the carcinoma and/or the presence of metastases. An increase in the serum levels of calcitonin was recorded in the course of the last six months and a series of tests have been performed. Chest X-ray was normal but computed tomography of the thorax showed a nodule in the right lower lobe of the lung (Figure A). As metastasis of the primary thyroid tumor was suspected, she underwent a thoracothomy to remove the nodule for diagnosis. Histology revealed the presence of $S$. mansoni eggs (containing miracidia remains) inside wellformed granulomas (Figure B), and surrounded by areas of interstitial fibrosis. In addition, small pulmonary arteries presented hypertrophy of the muscular layer, intimal hyperplasia, and, as a result, narrowing of the lumina (Figure C); findings which suggested the diagnosis of pulmonary hypertension. She recovered rapidly from surgery and was treated for schistosomiasis with praziquantel $(50 \mathrm{mg} / \mathrm{kg}$, body weight, single oral dose). Ultrasound of the abdomen showed no evidence of periportal fibrosis, splenomegaly or portal hypertension. She is being followed up at the outpatient clinic and is asymptomatic. This is an example of pulmonary involvement in the chronic intestinal form of schistosomiasis mansoni and should be considered in the differential diagnosis of primary and metastatic lung cancer.

A paciente, de 33 anos de idade, submeteu-se à tireoidectomia total para tratamento de carcinoma medular da tireóide sete anos antes da internação atual. Desde então, ela submete-se, periodicamente, a exames clínicos e laboratoriais com o objetivo de diagnosticar e tratar precocemente recidivas locais do tumor ou metástases. Nos últimos seis meses, notou-se aumento dos níveis de calcitonina no soro e, novamente, uma série de exames foram realizados. A radiografia do tórax era normal, mas, a tomografia computadorizada revelou a presença de nódulo pulmonar no lobo inferior direito do pulmão (Figura A). Com o diagnóstico presuntivo de metástase do tumor original da tireóide, ela submeteu-se à toracotomia para retirada do nódulo e investigação diagnóstica. A histologia revelou a presença de ovos embrionados de $S$. mansoni em granulomas bem constituídos (Figura B) e áreas de fibrose intersticial. Notouse também a presença de pequenas artérias e arteríolas com hipertrofia da camada muscular, fibrose intimal e estreitamento do lúmen dos vasos (Figura C), alterações estas sugestivas de hipertensão pulmonar. A paciente recuperou-se bem da cirurgia e foi tratada com praziquantel $(50 \mathrm{mg} / \mathrm{kg}$ de peso, em dose única por via oral). 0 ultra-som do abdômen não revelou a presença de fibrose periportal, esplenomegalia, ou evidências de hipertensão portal. A paciente continua sendo acompanhada em ambulatório e permanece assintomática. Este é um exemplo de envolvimento pulmonar na forma intestinal crônica da esquistossomose mansônica e que deve ser considerado no diagnóstico diferencial de neoplasias primárias ou secundárias do pulmão.

\section{REFERÊNCIAS BIBLIOGRÁFICAS}

1. Fatureto MC, Correia D, Silva MBO, Barra MFC, Silva AV, Tarquínio DC, Pacheco KD, Lima MA. Pulmonary schistosomotic nodule simulating neoplasia: case report. Revista da Sociedade Brasileira de Medicina Tropical 36: 735-737, 2003.

2. Lambertucci JR. Pulmonary nodules on CT scan of the lungs in acute schistosomiasis. British Journal of Radiology 75: 491, 2002.

3. Lambertucci JR, Rayes AA, Barata CH, Teixeira R, Gerspacher-Lara R. Acute schistosomiasis: report on five singular cases. Memórias do Instituto Oswaldo Cruz 92: 631-635, 1997. 